\title{
ANALISA TEKANAN DAN EFISIENSI PADA POMPA AIR SENTRIFUGAL DENGAN RANGKAIAN SERI
}

\author{
${ }^{(1)}$ Muhammad Riza Hidayat, ${ }^{(2)}$ Muhammad Firman, ${ }^{(3)}$ Muhammad \\ Suprapto \\ ${ }^{(1)(2)(3)}$ Prodi Teknik Mesin, Fakultas Teknik, Universitas Islam Kalimantan MAB \\ Jl. Adhiyaksa No. 2 Kayu Tangi, Banjarmasin \\ Email:muhammadrizahidayat@gmail.com,firmanuniska99@gmail.com, \\ muhammadsuprapto13@gmail.com
}

\begin{abstract}
ABSTRAK
Pompa sentrifugal adalah satu jenis pompa yang sering digunakan untuk memindahkan air secara aliran paksa dengan kecepatan tinggi oleh impeler. Analisa tekanan dan efisiensi pada pompa air sentrifugal dengan rangkaian seri bertujuan untuk mengetahui tinggi tekanan pompa. Hasil dari pengujian tekanan pompa menggunakan media air pada rangkaian seri dengan putaran yang berbeda dapat diperoleh data head tertinggi sebagai berikut: head 3,14m dengan efisiensi 1,69\%.
\end{abstract}

Kata Kunci : pompa sentrifugal, karakteristik piompa seri, head dan efisiensi

\section{PENDAHULUAN}

Pompa merupakan pesawat angkut yang bertujuan untuk memindahkan zat cair melalui saluran tertutup. Pompa menghasilkan suatu tekanan yang sifatnya hanya mengalir dari suatu tempat ke tempat yang bertekanan lebih rendah. Atas dasar kenyataan tersebut maka pompa harus mampu membangkitkan tekanan fluida sehingga dapat mengalir atau berpindah. Fluida yang dipindahkan adalah fluida inkompresibel atau fluida yang tidak dapat dimampatkan. Dalam kondisi tertentu pompa dapat digunakan untuk memindahkan zat padat yang berbentuk bubukan atau tepung.

\section{TINJAUAN PUSTAKA}

\section{Pompa Sentrifugal}

Pompa sentrifugal adalah suatu mesin kinetis yang mengubah energi mekanik menjadi energi fluida menggunakan gaya sentrifugal, pompa sentrifugal terdiri dari sebuah cakram dan terdapat sudu-sudu,arah putaran sudu-sudu itu biasanya dibelokkan kebelakang terhadap arah putaran (Solarso, 2004)

Pada perancangan pompa sentrifugal dengan rangkaian seri ada ketentuan yang digunakan dalam perhitungan dasar-dasar perhitungan dalam menentukan suatu besaran satuan. Berikut persamaan dalam perancangan pompa sentrifugal rangkain seri:

1. Menurut Astu pudjanarsa, dkk (2006) tekanan total pompa yang tersedia harus dapat mengalirkan fluida sejumlah yang dibutuhkan. Head total dicari dari persamaan :

$$
\begin{aligned}
& \mathrm{H} 1=\frac{p \mathbf{d} 1-p \mathbf{s} 1}{y}(\mathrm{~m}) \\
& \mathrm{H} 2=\frac{p \mathbf{d} 2-p \mathbf{s} 2}{y}(\mathrm{~m}) \\
& \text { Htotal }=\mathrm{H} 1+\mathrm{H} 2(\mathrm{~m})
\end{aligned}
$$

Dimana :

Ps : Tekanan hisap $(\mathrm{Pa})$

$\mathrm{Pd}$ : Tekanan buang $(\mathrm{Pa})$ 


\section{Fungsi Komponen-komponen pompa}

a. Stuffing box

Berfungsi untuk menerima kebocoran pada daerah dimana poros pompa menembus casing.

b. Packing

Digunakan untuk mencegah dn mengurangi bocoran cairan dari casing pompa melalui poros.

c. Shaft (poros)

Poros berfungsi untuk meneruskan momen punter dari penggerak selama beroperasi dan tempat kedudukan impeller dan bagian-bagian berputar lainnya.

d. Shaft sleeve

Shaft sleeve berfungsi untuk melindungi poros dari erosi, korosi dan keausan pada stuffing box.

e. vane

Sudu dari impeller sebagai tempat berlalunya cairan pada impeller.

f. Casing

Merupakan bagian paling luar dari pompa yang berfungsi sebagai pelindung elemen yang berputar, tempat kedudukan diffuser (guide vane), inlet dan outlet nozel serta tempat memberikan arah aliran dari impeller dan mengkonversikan energi kecepatan cairan menjadi energi dinamis (single stage)

g. Eye of impeller

Bagian pada sisi masuk pada arah isap impeller

h. Impeller

Impeller berfungsi untuk mengubah energi mekanis dari pompa menjadi energi kecepatan pada cairan yang dipompakan secara kontinyu, sehingga cairan pada sisi isap secara terus menerus akan masuk mengisi kekosongan akibat perpindahan dari cairan yang masuk sebelumnya.

i. Chasing Wear Ring

Chasing Wear Ring berfungsi untuk memperkecil kebocoran cairan yang melewati bagian depan impeller maupun bagian belakang impeller, dengan cara memperkecil celah antara casing dengan impeller.

j. Discharge nozel

Discharge nozel berfungsi untuk mengeluarkan cairan dari impeller, didalam nosel ini sebagian head kecepatan aliran diubah menjadi head tekanan.

\section{HASIL DAN PEMBAHASAN}

Dalam penelitian ini telah dibuat rangkaian pompa dengan sususan seri. Perakitan pompa susunan seri ini menggunakan pipa dengan ukuran $3 / 4$ $\mathrm{mm}$, susunan ini menggunakan dua buah pompa tipe sentrifugal dengan memanfaatkan putaran motor.

Pada ketiga pengujian ini masing-masing variable diperoleh hasil tekanan aliran :

\begin{tabular}{|c|c|c|c|c|c|c|c|c|c|}
\hline \multirow[b]{3}{*}{ no } & \multirow{3}{*}{$\begin{array}{l}\text { putaran } \\
\text { motor }\end{array}$} & \multicolumn{8}{|c|}{ tekanan aliran } \\
\hline & & \multicolumn{2}{|l|}{1} & \multicolumn{2}{|l|}{2} & \multicolumn{2}{|l|}{3} & \multicolumn{2}{|c|}{ rata-rata } \\
\hline & & In & Out & in & out & in & out & in & Out \\
\hline 1 & $\begin{array}{l}1000 \\
\mathrm{rpm}\end{array}$ & 7921 & 33117 & 7933 & 32998 & 7918 & 32105 & 7924 & 32740 \\
\hline 2 & $\begin{array}{l}1200 \\
\text { rpm }\end{array}$ & 9316 & 37265 & $929 \times 8$ & 37252 & 9321 & 37270 & 9311 & 37262 \\
\hline 3 & $\begin{array}{l}1400 \\
\mathrm{rpm}\end{array}$ & 10856 & 42337 & 10847 & 42331 & 10852 & 42342 & 10851 & 42336 \\
\hline
\end{tabular}

Dari hasil tekanan aliran yang didapat pada tabel diatas, kita dapat menghitung efisiensi dari pompa pada masing-masing variable dengan menggunakan rumus persamaan :

\begin{tabular}{|l|l|l|l|l|l|l|}
\hline \multirow{2}{*}{ No } & \multirow{2}{*}{$\begin{array}{l}\text { putaran } \\
\text { motor }\end{array}$} & \multicolumn{2}{|l|}{ tekanan aliran } & \multirow{2}{*}{ head } & \multirow{2}{*}{ efisiensi } \\
\cline { 3 - 6 } & Pin & Pout & AP & & \\
\hline 1 & $\begin{array}{l}1000 \\
\mathrm{rpm}\end{array}$ & 7924 & 32740 & 24816 & $2,48 \mathrm{~m}$ & $1,24 \%$ \\
\hline 2 & $\begin{array}{l}1200 \\
\mathrm{rpm}\end{array}$ & 9311 & 37262 & 27951 & $2,79 \mathrm{~m}$ & $1,48 \%$ \\
\hline 3 & $\begin{array}{l}1400 \\
\mathrm{rpm}\end{array}$ & 10851 & 42336 & 31485 & $3,14 \mathrm{~m}$ & $1,69 \%$ \\
\hline
\end{tabular}

Menghitung efesiensi dengan menggunakan persamaan rumus sebagai berikut :

1. Pada putaran $1000 \mathrm{rpm}$ 


$$
\begin{aligned}
& \eta=\frac{92564}{74404} 100 \%=1,24 \% \\
& W_{h p}=24816 \times 3,73=92564 \\
& =>Q=\frac{0,189}{1000} \sqrt{2,48}=\quad 0,017 \mathrm{~m}^{3} / \\
& \text { menit }=>3,73 \mathrm{gpm} \\
& =>h=\frac{24816}{1000.10}=2,48 \mathrm{~m} \\
& B_{h p}=380 \text { volt } \times 220 \mathrm{~A} \times 0,89=74404
\end{aligned}
$$

2. Pada putaran $1200 \mathrm{rpm}$

$\eta=\frac{110406}{74404} 100 \%=1,48 \%$

$W_{h p}=27951 \times 3,95=110406$

$=>Q=\frac{0,189}{1000} \sqrt{2,79}=0,019 \mathrm{~m}^{3} /$

menit $=>3,95 \mathrm{gpm}$

$=>h=\frac{27951}{1000.10}=2,79 \mathrm{~m}$

$B_{h p}=380$ volt $\times 220 \mathrm{~A} \times 0,89=74404$

3. Pada putaran $1400 \mathrm{rpm}$

$$
\begin{aligned}
& \eta=\frac{125788}{74404} 100 \%=1,69 \% \\
& W_{h p}=31845 \times 3,95=125788 \\
& =>Q=\frac{0,189}{1000} \sqrt{3,14}=\quad 0,021 \mathrm{~m}^{3} / \\
& \text { menit }=>4,62 \mathrm{gpm} \\
& =>h=\frac{31485}{1000.10}=3,14 \mathrm{~m} \\
& B_{h p}=380 \text { volt } \times 220 \mathrm{~A} \times 0,89=74404
\end{aligned}
$$

\section{analisa data}

dari hasil pengujian yang dilakukan didapat hasil pada tabel diatas, dari hasil yang didapat pada tabel maka dibuat sebuah grafik untuk menganalisa hasil dari pengujian yang dilakukan. Seperti pada grafik dibawah ini :

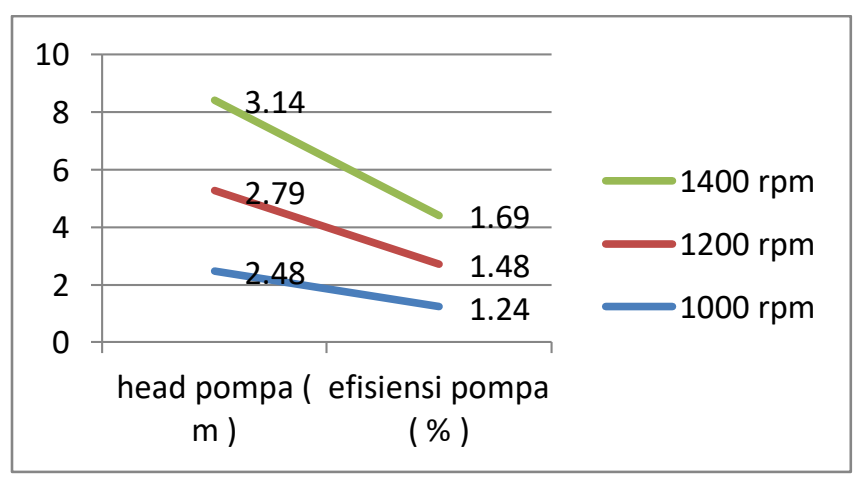

Dari hasil analisa data grafik diatas dapat disimpulkan bahwa dengan putaran motor 1400 rpm didapatkan hasil head tertinggi $3,14 \mathrm{~m}$ dengan efisiensi pompa $1,69 \%$, putaran motor $1200 \mathrm{rpm}$ diperoleh hasil head pompa 2,79 $\mathrm{m}$ dan efisiensi pompa $1,48 \%$, dan pada putaran 1000 rpm didapatkan head pompa 2,48 $\mathrm{m}$ dan efisiensi pompa 1,24 $\%$. Sehingga kinerja pompa yang didapat pada head dan efisiensi tertinggi didapat pada putaran motor dengan kecepatan putaran $1400 \mathrm{rpm}$.

\section{KESIMPULAN}

Dari hasil pengujian dan anlisa data diatas maka dapat disimpulkan kinerja pompa sentrifugal dengan rangkaian seri menghasilkan :

1. Dari hasil beberapa pengujian pada variable putaran motor dihasilkan seri tekanan air pada putaran motor $1000 \mathrm{rpm}$ ialah 2,48 m, pada putaran motor 1200 rpm dihasilkan head tekanan pompa $2,79 \mathrm{~m}$, dan pada putaran motor 1400 rpm didapatkan hasil 3,14 m. Sehingga semakin panjang jarak daya dorong air semakin banyak pula tekanan yang didapat.

2. Pada pengujian ini dihasilkan efisiensi pada masing-masing variable putaran motor. Pada putaran 1000 rpm dihasilkan efisiensi 1,24\%, pada putaran 1200 rpm dihasilkan efisiensi $1,48 \%$, dan pada putaran $1400 \mathrm{rpm}$ didapat hasil efisiensi sebesar $1,69 \%$.

\section{REFERENSI}

[1] Edi Widodo (2017) 'Redesain Pump Observation Untuk Meningkatkan Fleksibilitas dan Efektifitas '( Universitas Muhammadiyah Sidoarjo Oktober 2017 ).

[2] Wahyu Sulistya (2014) 'Perencanaan Perawatan dan Perbaikan Alat Peraga Instalasi Pompa Jenis Sentrifugal Kapasitas 30L/menit'. 
[3] Hardiman Simbolon (2015) 'Analisa Efesiensi Pompa Sentrifugal (Vogel Pump) di PT.Krakatau Steel,DivisiSlab Steel Plant'.

[4] Syamsul Husda (2014) 'Studi Literatur Tentang Program Pump System Improvement Modeling Tool untuk Penyempurnaan Kinerja Sistem Pompa'.

[5] Firdaus Amirullah (2009) 'Pengujian Karakteristik Pompa Susunan Paralel dan Seri'

[6] Djati Nursuhud (2006) 'Analisa Performa Pompa Sentrifugal Susunan Tunggal,Seri,dan Paralel 